навчальні матеріали;

- інтерактивність, тобто студенти отримують можливість зворотного зв'язку, який інформує їх щодо правильності дій. Такий зворотній зв’язок може бути як оперативним, так і відстроченим у вигляді оцінки;

- підвищення мотивації за рахунок створення умов, які сприяють підвищенню зацікавленості предметом;

- можливість автоматизованого контролю, урахування результатів навчального процесу та більш об’єктивного оцінювання знань та умінь [4; 5; 6].

Використання інформаційних технологій в організації самостійної навчальної діяльності студентів дозволяє не тільки інтенсифікувати їх роботу, а й закладає основи їх подальшої постійної самоосвіти, отже, педагогічне інформаційно-освітнє середовище, яке створюється за допомогою інтеграції сукупності програмно-апаратних та традиційних форм навчання, і визначає самостійну навчальну діяльність студента як більш незалежну і творчу.

\title{
Література
}

1. Гершунский Б. С. Компьютеризация в сфере образования: Проблемы и перспективы : [учеб. пос.] / Б. С. Гершунский. - Москва : Педагогика, 1987. - 264 с. 2. Котляр Л. М. Организация самостоятельной работы по математике с помощью современных информационных технологий / Л. М. Котляр, Ж. И. Зайцева, Л. Б. Фоменко // Фундаментальные исследования. - 2004. - № $5-\quad$ С. 15-18. $\quad$ 3. Лобачев С. Л. Информационно-образовательная среда открытого образования / С. Л. Лобачев, А. Поляков // Народное образование. - 2000. - № 8. - С. 43-47. 4. Полат Е. С. Новые педагогические и информационные технологии в системе образования: [учеб. пособ.]/ Е. С. Полат. - Москва : Издательский центр «Академия», 2005 - 272 с. 5. Положення про організацію навчального процесу у вищих навчальних закладах: Затверджене Наказом МОН України від 2.06.93 № 161. 6. Роберт И. В. Информационные и коммуникационные технологии в образовании : [учеб. пособ.] / И. В. Роберт. - Москва : Дрофа, 2008. - 312 с. 7. Селевко Г. К. Педагогические технологии на основе информационно-коммуникационных средств: [учеб. пособ.] / Г. К. Селевко. - Москва : НИИ школьных технологий, 2004. - 224 с.

УДК 378.147:510.6:004

Марія Медведєва

\section{ВИКОРИСТАННЯ ОСВІТНЬОГО РЕСУРСУ У ВИГЛЯДІ САЙТУ «ДИСКРЕТНА МАТЕМАТИКА» ЗА УМОВ ОСОБИСТІСНО ЗОРІЄНТОВАНОГО НАВЧАННЯ}

Медведєва М. О. Використання освітнього ресурсу у вигляді сайту «Дискретна математика» за умов особистісно зорієнтованого навчання.

У статті обгрунтовано актуальність та доцільність використання освітнього Інтернетресурсу у вигляді сайту «Дискретна математика», що використовується за особистісно зорієнтованого навчання дискретної математики з використанням інформаційних технологій у вищих навчальних закладах. Описано технології, що використовувалися під час створення пропонованого сайту.

Ключові слова: дискретна математика, інформаційні технології, вищий навчальний заклад, особистісно зорієнтоване навчання, навчально-пізнавальна діяльність.

Медведева М. А. Использование образовательного ресурса в виде сайта «Дискретная 
математика» в условиях личностно ориентированного обучения.

В статье обоснована актуальность и целесообразность использования образовательного Интернет-ресурса в виде сайта «Дискретная математика», используемый по личностно ориентированного обучения дискретной математики с использованием информационных технологий в высших учебных заведениях. Описаны технологии, использовавшиеся при создании данного сайта.

Ключевые слова: дискретная математика, информационные технологии, высшее учебное заведение, личностно ориентированное обучение, учебно-познавательная деятельность.

Medvedyeva M. O. Using «Discrete Mathematics» site as an educational resource in terms of personal based learning.

In the article the relevance and usefulness of educational resource «Discrete Mathematics», used for the person centered education of Discrete Mathematics with the aids of information technology in higher educational institution are analysed. The technology used to create the site wre described.

Key words: Discrete Mathematics, information technology, higher educational institution, person centered learning, training and cognitive activities.

Модернізація вищої освіти України передбачає розв’язання проблем, пов’язаних з її інформатизацією й особистісною орієнтацією, індивідуалізацією навчально-виховного процесу, зокрема на рівні вищої освіти [1; 2]. Динамізм сучасного соціального й економічного життя, зростаючі вимоги до майбутніх фахівців зумовлюють зміну пріоритетів в організації навчально-виховного процесу, його спрямованість на особистісно-професійний розвиток випускника, на забезпечення передумов для розкриття його потенціалу [4].

Підгрунтям нашого дослідження стали наукові роботи, присвячені розвитку педагогіки, методики та методології вищої освіти: А. Алексюк, С. Вітвіцька, В. Кремень, М. Фіцула, А. Хуторський; упровадженню особистісно зорієнтованих технологій у навчально-виховний процес: Б. Беспалько, О. Бондаревська, О. Газман, Л. Карташова, О. Пєхота, І. Підласий, О. Полат; інформаційним технологіям в освіті, зокрема вищій: А. Гуржій, Р. Гуревич, М. Жалдак, В. Луговий, В. Мадзігон, Н. Морзе, Ю. Рамський, I. Роберт, Ю. Триус.

Мета статmі - обгрунтувати актуальність та доцільність використання освітнього Інтернет-ресурсу у вигляді сайту «Дискретна математика», що використовується за особистісно зорієнтованого навчання дискретної математики 3 використанням інформаційних технологій у вищих навчальних закладах.

Використовуючи засоби інформаційних технологій у навчальному процесі, слід якнайповніше застосувати їх можливості автоматизації, а отже, об’єктивізації і спрощення контролюючих етапів навчання, що надає можливість, зокрема, студентам здійснювати самоконтроль у зручному для них режимі - одне з перших завдань, для розв’язання яких IT були застосовані у освіті.

Усе більшого розвитку набувають нові системи навчання, засновані на ефективному використанні в навчально-виховному процесі ВНЗ сучасних засобів і методів передавання, засвоєння та контролю знань.

Ефективність процесу навчання залежить від частоти й оперативності, 3 якими контролюється перебіг і ступінь засвоєння навчального матеріалу. 3 розвитком інформаційних технологій має місце можливість організації особистісно зорієнтованого 
навчання шляхом розробки освітнього ресурсу у вигляді сайту 3 використанням інформаційних технологій [3].

Для створення сайту «Дискретна математика» були використані найбільш зручні й ефективні технології, а саме:

HTML5 - стандартна мова розмітки документів у Всесвітній мережі. Більшість вебсторінок створюються за допомогою мови HTML (або XHTML). Документ HTML оброблюється браузером та відтворюється на екрані у звичному для людини вигляді. HTML $\epsilon$ похідною мовою від SGML, успадкувавши від неї визначення типу документу та ідеологію структурної розмітки тексту. HTML разом із CSS та скриптингом - це три основні технології побудови веб-сторінок.

За допомогою HTML5 на сайті «Дискретна математика» було реалізовано:

1. Створення структурованого документу шляхом позначення структурного складу тексту: заголовки, абзаци, списки, таблиці, цитати та інше;

2. Інтерактивні форми реєстрації;

3. Унесення зображень, звуку, відео, та інших об’єктів до тексту.

CSS3 - спеціальна мова, що використовується для відображення сторінок, написаних мовами розмітки даних. Найбільш часто CSS використовують для візуальної презентації сторінок, написаних HTML та XHTML, але формат CSS може застосовуватися до інших видів XML-документів. CSS (каскадна або блочна верстка) прийшла на заміну табличній верстці веб-сторінок. Головна перевага блочної верстки - розділ змісту сторінки (даних) та їх візуальної презентації. Ми використали каскадні таблиці стилів для візуального оформлення нашого сайту та додавання до деяких елементів нових властивостей, наприклад, для квадратних елементів ми застосували округлення кутів, градацію кольорів у так званій «шапці» сайту та створення тіней для заголовків тексту.

JQuery 1.4.4 - популярний JavaScript-фреймворк із відкритим програмним кодом. Основне завдання jQuery - це надавати розробнику легкий та гнучкий інструментарій кросбраузерної адресації DOM об’єктів за допомогою CSS та XРаth селекторів. Також даний фреймворк надає інтерфейси для Ајах-застосувань, обробників подій і простої анімації. Принцип роботи jQuery полягає у використанні класу (функції), який при звертанні до нього повертає сам себе. У такий споіб, це дозволяє будувати послідовний ланцюг методів. За допомогою JQuery на нашому сайті реалізовані динамічні тексти у блоці реєстрації користувачів, рейтинг статей студентів та «випадаюча» панель реєстрації.

MySQL 5.1 - вільна система керування реляційними базами даних. MySQL вважається вдалим рішенням для малих і середніх застосувань. Вихідні коди сервера компілюються на багатьох платформах. Найповніше можливості сервера виявляються в UNIX-системах, де є підтримка багатонитевості, що підвищує продуктивність системи в цілому. Для некомерційного використання MySQL є безкоштовним. Можливості сервера MySQL:

- простота у встановленні та використанні;

- підтримується необмежена кількість користувачів, що одночасно працюють із БД;

- кількість рядків у таблицях може досягати 50 млн.;

- висока швидкість виконання команд;

- наявність простої і ефективної системи безпеки.

MySQL надає можливість зберігати великий об’єм даних у зручній формі і при необхідності «витягати» ї̈ з бази даних. За допомогою зв’язку між MySQL i мовою 
програмування РНР можна створювати динамічні сторінки. Тепер не потрібно створювати безліч однотипних сторінок з різною інформацією, можна просто створити одну і за допомогою якого-небудь параметру витягати інформацію з бази даних, тим паче це надає змогу у майбутньому дуже зручно редагувати і дизайн сайту, оскільки структура сайту буде складатися не з 1000 сторінок, а, наприклад, як у нашому випадку, з 15 сторінок, і коли нам потрібно буде змінити дизайн на всіх сторінках, ми можемо редагувати один, тоді як зміни відобразяться на інших. У нашій базі даних зберігається інформація про дисципліни, модульні контролі, самостійні роботи, контрольні тестування та загальні тексти сайту.

PHP 5 - попередня назва: Personal Home Page Tools - скриптова мова програмування, була створена для генерації HTML-сторінок на стороні веб-сервера. PHP є однією 3 найпоширеніших мов, що використовуються у сфері веб-розробок (разом із Java, .NET, Perl, Python, Ruby). РHP підтримується переважною більшістю хостинг-провайдерів. РНР інтерпретується веб-сервером в HTML-код, який передається на сторону клієнта. На відміну від скриптової мови JavaScript, користувач не бачить РНР-коду, бо браузер отримує готовий HTML-код. Це є перевага з позиції безпеки, але погіршує інтерактивність сторінок. Але ніщо не забороняє використовувати РНP для генерування і JavaScript-кодів які виконаються вже на стороні клієнта. Мова програмування РНР використана для створення динамічних сторінок сайту, створення динамічних тестів, бази оголошень, бази статей студентів та інше. Структурна схема бази даних сайту «Дискретна математика» представлена на рис. 1.

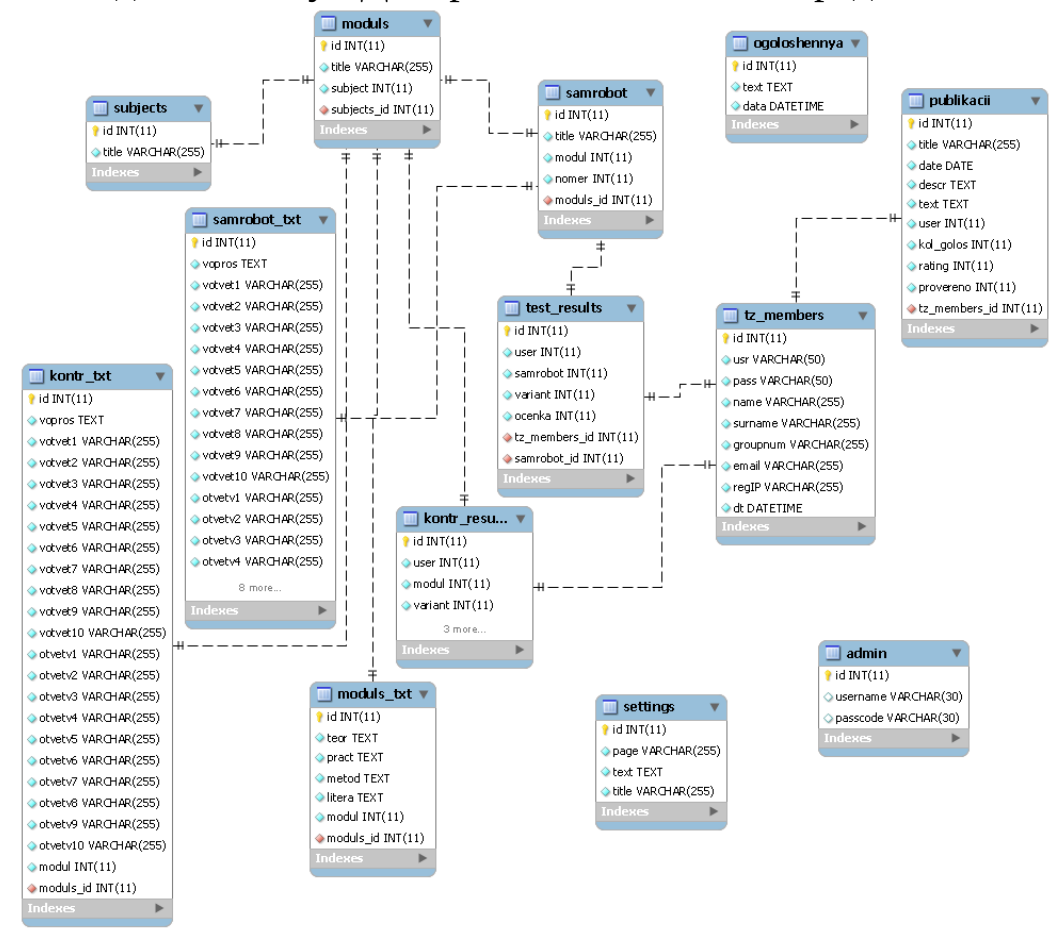

Рис. 1. Структурна схема бази даних сайту «Дискретна математика»

Головна сторінка (рис. 2): реєстрація та вхід користувачів; дисципліни; форум; корисні посилання; оголошення; публікації.

Для того, щоб повноцінно користуватися сайтом «Дискретна математика» користувачу потрібно зареєструватися. Блок реєстрації та форма для реєстрації знаходиться на головній сторінці сайту. Форма реєстрації включає у себе такі поля: Логін; Ім'я; Прізвище; Група; Електронна пошта.

Після того, як користувач введе всі дані система автоматично згенерує пароль і 
надішле його на пошту користувача. Далі можна увійти на сайт, заповнивши форму входу, після входу логін користувача автоматично запам'ятовується і можна користуватися усіма функціями сайту, у тому числі перевіряти результати своїх самостійних робіт і результати своїх контрольних тестувань.

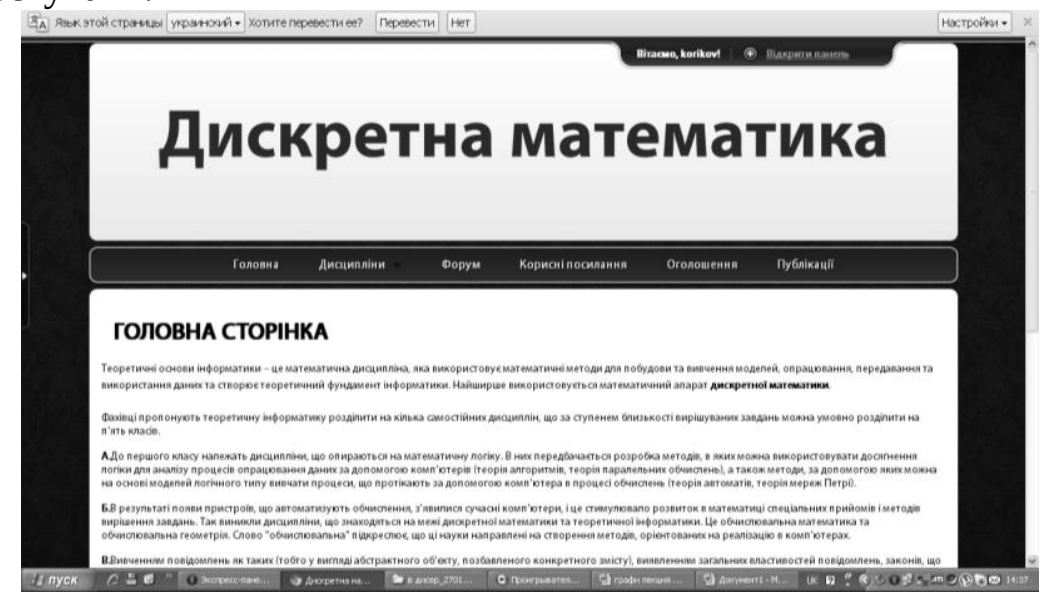

Рис. 2. Головна сторінка сайту «Дискретна математика»

На головній сторінці відображається загальний контент сайту, він може бути у будьякому електронному вигляді, не обов'язково у вигляді тексту, а ще й у вигляді аудіо та відеоконтенту.

Розділ «Дисципліни» (рис. 3) надає змогу студентам обрати дисципліну для виконання самостійної роботи та модульних контролів.

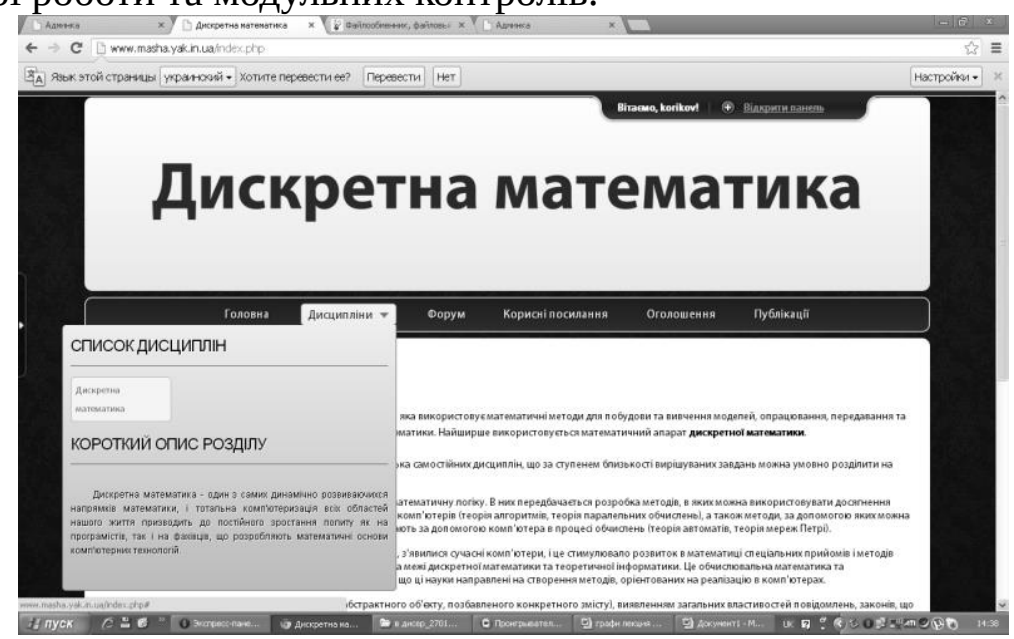

Рис. 3. Розділ «Дисципліни» сайту «Дискретна математика»

Назви дисциплін та їх кількість можуть бути додані в адміністраторській частині сайту, доступ до якого має тільки адміністратор сайту. Після того, як студент обере дисципліну, відобразяться змістові модулі цієї дисципліни (рис. 4), кількість модулів та їх назви також редагуються адміністратором. 


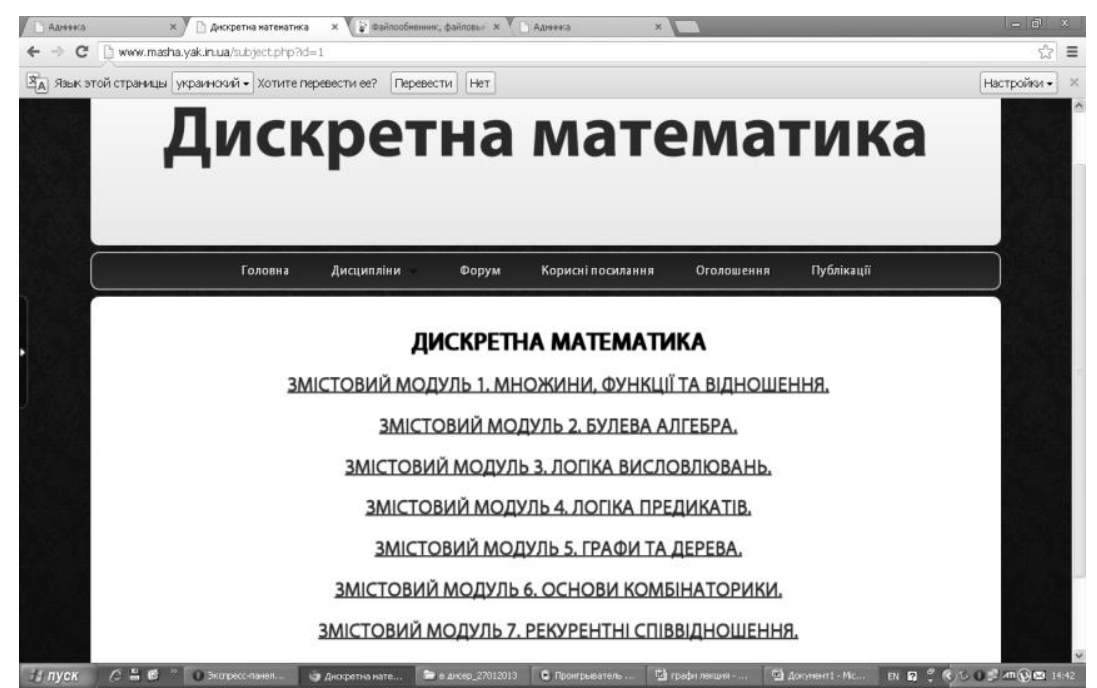

Рис. 4. Змістові модулі дисципліни «Дискретна математика»

Спочатку, якщо студент не склав жодний модульний контроль, він може зайти тільки у перший модульний контроль обраної дисципліни.

У кожному змістовому модулі існують свої розділи: «Теоретичні матеріали», «Практичні заняття», «Методичні вказівки до виконання практичних завдань», «Завдання до самостійної роботи студента», «Контрольне тестування», «Література».

У розділах «Теоретичні матеріали», «Практичні заняття», «Методичні вказівки до виконання практичних завдань», «Література» зберігається тільки текстова інформація, а також посилання на матеріали, які можна завантажити.

У розділах «Завдання до самостійної роботи студента», «Контрольне тестування» зберігаються тестові завдання для оцінки знань студентів з обраного модульного контролю.

Розділ «Завдання до самостійної роботи студента» включає у себе самостійні роботи обраного модульного контролю. Студент не може перейти до виконання наступної самостійної роботи, якщо його бал за попередню буде нижче 8. Формат розділу - тестовий, тобто користувач, обравши самостійну роботу, обирає свій варіант самостійної роботи і відповідає на тестові питання згідно з обраним варіантом.

Кількість питань у тесті може бути необмежена адміністратором сайту, але кількість варіантів відповідей повинна бути 10. Ідеально робити 10 питань і 10 варіантів відповідей. Якщо студент не зміг набрати в кінці тестування 8 балів, то він не може перейти до наступної самостійної роботи, але може спробувати скласти цю самостійну роботу ще раз. У такому випадку відомості щодо виконання ним цієї самостійної роботи оновлюється у базі. У разі, якщо студент склав усі самостійні роботи на більше або 8 балів, він може перейти до контрольного тестування.

Розділ «Контрольне тестування» має такий самий тестовий формат як і розділ «Завдання до самостійної роботи студента». Якщо студент набрав 8 правильних відповідей, він може перейти до наступного модульного контролю обраної раніше дисципліни.

В адміністраторський частині сайту викладач має змогу слідкувати за тим, як виконуються самостійні роботи і контрольні тестування.

Розділ основного меню «Форум» веде користувача на форум «Дискретна математика», де можна обмінюватися своїм досвідом 3 іншими користувачами, ставити запитання та давати на них відповіді.

Розділ «Корисні посилання» вміщає у себе посилання на інші освітні ресурси 3 
дискретної математики у мережі Інтернет.

Розділ «Оголошення» відображає оголошення викладача у текстовому форматі, переглядати цей розділ мають можливість тільки зареєстровані користувачі.

Розділ «Публікації» надає можливість користувачам переглядати публікації інших студентів та оцінювати їх за десятибальною шкалою. На головній сторінці у випадаючому меню входу є можливість додавати свої публікації на сайт. Після перегляду публікації адміністратором і її ухвалення, вона потрапляє у розділ «Публікації», де вже доступна для інших користувачів.

Отже, застосування комп’ютерів як засобів навчання дискретної математики створює передумови для вдосконалення традиційних методик навчання. Перевага використання комп’ютера, як засобу навчання, в порівнянні з іншими технічними засобами навчання полягає в тому, що він одночасно є інформаційним, контролюючим і навчальним засобом, що $\epsilon$ особливо важливим в умовах особистісно зорієнтованої системи навчання дискретної математики.

Спрямованість на професійно особистісне самовизначення, самоорганізацію, самореалізацію як найважливіші компоненти саморозвитку особистості, повинно зайняти провідне місце в навчально-виховному процесі ВНЗ, зокрема - в навчанні дискретної математики у вищому навчальному закладі.

\section{Література}

1. Інформаційні технології і засоби навчання / [за ред. В. Ю. Бикова, Ю. О. Жука]. Київ : Атіка, 2005. - 272 с. 2. Кронбергская декларация о будущем процессов приобретения и передачи знаний / UNESCO High Level Group of Visionaries on Knowledge Acquisition and Sharing. - Кронберг, 2007 [Электронный ресурс]. - Режим доступа : http://www.ifap.ru/library/ book199.pdf. 3. Литвиненко М. В. Структурно-функциональная модель индивидуальной траектории обучения в условиях информатизации образования : автореф. дисс. на соискание ученой степени докт. пед. наук : спец. 13.00.01 «Общая педагогика, история педагогики», 13.00.02 «Теория и методика обучения и воспитания» / М. В. Литвиненко. - Москва, 2007. 46 с. 4. Луговий В. I. Інформаційне забезпечення вищої школи України / В. Луговий, Н. Халікян // Вища освіта України. - 2007. - № 3. - С. 48-51.

УДК 371.91(07)

Олександр Надтока, Тетяна Мартинюк

\section{ЗАСТОСУВАННЯ ДІЯЛЬНІСНОГО ПІДХОДУ ЯК ОДНОГО 3 АСПЕКТІВ ДОСЛІДЖЕННЯ МЕТОДИКИ НАВЧАННЯ ГЕОГРАФІЇ}

Надтока О. Ф., Мартинюк Т. С. Застосування діяльнісного підходу як одного 3 аспектів дослідження методики навчання географії.

У статті розглядаються питання, що стосуються проблематики методичних засад навчання географії на основі діяльнісного підходу. Вони спираються на переосмислення ролі вчителя й учня у процесі навчання географії в загальноосвітніх навчальних закладах. Результатами впровадження діяльнісного підходу в навчанні $є$ набуття учнями досвіду практично-дослідної діяльності, формування особистісного розвитку через власну траєкторію навчання; розвиток емоційно-ціннісного ставлення до географічного пізнання; формування в учнів здатності до самоосвіти, критичного і прогностичного мислення, а на його основі - ключових та предметної компетентностей. Усе зазначене вище зумовлене необхідністю адекватного відображення відповідної географічної картини світу 